\title{
Soil Bioaugmentation with Pseudomonas aeruginosa S-CSR-0013 Eliminates the Inhibitory Effect of Phenol on Germination of Chickpea (Cicer arietinum) Seeds
}

\author{
P.T. Amrutha Vijay, M.M. Sahila, A.A. Mohammad Kunhi* \\ SIAS-Centre for Scientific Research, SAFI Institute of Advanced Study (SIAS), P.O. Vazhayoor East, Malappuram - 673 633, Kerala, India.
}

\section{ART ICLEDETAILS}

Article history:

Received 04 May 2020

Accepted 21 May 2020

Available online 26 May 2020

\section{Keywords:}

Seed Germination Inhibition

Seedling Vigour

Bioaugmentation

Pseudomonas aeruginosa

\begin{abstract}
A B S T R A C T
Phenol is one of the 50 bulkiest chemicals produced in the world and is one of the priority pollutants found in various industrial effluents at varying levels. Its toxicity to fauna and flora has been well established. However, information on its effect on germination of crop seeds is scanty. In this study the effects of phenol on germination of 11 different crop seeds were tested by filter paper as well as soil methods. Chickpea, mung bean, and long-podded cowpea seeds were found to be highly sensitive with drastic reduction in germination percentage (GP) and seedling vigour (SV) in the presence of phenol even at very low concentrations, chickpea being most vulnerable. Marked decrease in protease and amylase activities in germinating seeds was also observed. Seed viability was inversely proportional to the concentration of phenol. The inhibitory effect of phenol on germination was eliminated effectively by bioaugmentation of the soil with Pseudomonas aeruginosa S-CSR-0013. Pre-inoculation of the soil eight days before sowing the seeds exhibited complete protection of GP and SV. The bacterium degraded phenol efficiently from the soil with concomitant growth. It can be concluded that phenol-contaminated soils could be effectively bioremediated to enable normal seed germination and seedling growth.
\end{abstract}

\section{Introduction}

Phenol is ubiquitous in nature as it is a natural constituent of various plants and animals as well as due to its synthesis and use in large quantity as an industrial chemical. Naturally, it is a constituent of decomposing organic material, human and animal wastes, as well as coal tar and creosote. Phenol is also formed during forest fires, and by atmospheric degradation of benzene in the presence of light. Phenol is one of the 50 major industrial chemicals produced in the world. The production of phenol in 2017 was around 8.9 million tons and is projected to reach approximately 12.11 million tons by the end of 2023 [1]. Phenol is a basic structural unit for a variety of synthetic organic compounds including agricultural and industrial chemicals and pharmaceuticals such as phenolic resins, bisphenol-A, caprolactam, adipic acid, alkylphenols, aniline, and chlorinated phenols, and also used as a slimicide, a disinfectant, and a reagent in research laboratories [2].

Phenol is highly toxic to flora and fauna including humans. It also causes taste and odour problems in drinking water at far lower concentrations [3]. As phenol and its derivatives are generated by various industries such as petroleum refining, petrochemical, coke conversion, pharmaceutical, plastic, and resin manufacturing its concentration in the waste effluents may vary from traces to $15000 \mathrm{mg} / \mathrm{L}$. United States Environmental Protection Agency (U.S.EPA) and Central Pollution Control Board (CPCB) of India have prescribed maximum permissible limits of 3.4 and $5.0 \mathrm{mg} / \mathrm{L}$, respectively of phenol in industrial waste discharges. Concentrations as low as $0.005 \mathrm{mg} / \mathrm{L}$ can cause adverse effects on the aquatic environment while $0.8 \mathrm{mg} / \mathrm{kg}$ soil is considered toxic [4,5].

In soils large amounts of phenolic compounds are released from decomposing plant litter and they have been shown to be involved in inhibitory allelopathic interactions [6,7]. Olive mill wastewater and dry olive residue also have been found to be highly phytotoxic due to the low molecular weight phenolic compounds present in them and attempts to remove them by various means including fungal biodegradation have been reported by several workers [8-10].

However, information on phytotoxicity of phenol as such is rather scanty except that of retarded growth of corn plants in its presence $[11,12]$. Phytotoxicity of phenol and 2,4,6-trichlorophenol to local crop 
soil with bacterial strains capable of degrading the respective compounds has been reported $[22,23]$.

The present work deals with the data on the inhibitory effect of phenol on germination of various crop seeds with particular emphasis on chickpea (Cicer arietinum) seeds. A bacterial strain isolated in our laboratory by phenol-enrichment of a soil sample from the vicinity of a petrol station, identified and designated as Pseudomonas aeruginosa SCSR-0013 was found to be capable of degrading phenol effectively in shake flasks. Also, this present work carried out to study the effectiveness of this strain in bioremediation of phenol-spiked soil and present here the data on how the inhibitory effect of phenol on seed germination was revoked.

\section{Experimental Methods}

\subsection{Seed Germination Tests}

Seed germination tests were conducted on moist filter paper as well as in soil. Seeds of 11 different representative crops such as spinach (Spinacia oleracea), cucumber (Cucumis sativus), brinjal or eggplant (Solanum melongena), tomato (Solanum lycopersicum), maize (Zea mays), pumpkin (Cucurbita maxima), okra (Abelmoschus esculentus), red chilli (Capsicum annum), chickpea (Cicer arietinum), mung bean or green gram (Vigna radiata), and long-podded cowpea (Vigna unguiculata subsp. sesquipedalis) were used in the study. The seeds were procured from local farmers.

\subsubsection{Germination Test on Filter Paper}

Germination on filter paper was tested according to a slightly modified method of International Seed Testing Association [29]. All the seeds mentioned above were screened for their response to phenol. Filter paper discs $(9 \mathrm{~cm})$ were placed in 2 layers in each $10 \mathrm{~cm}$ petri dish. The filter papers were moistened with different concentrations of phenol $(0,100$, 200, 400, 600, 800 and $1000 \mathrm{mg} / \mathrm{L}$ ). In each petri plate 25 seeds were placed, covered with the lid, and incubated at ambient temperature (22$28{ }^{\circ} \mathrm{C}$ ) under $12-12 \mathrm{~h}$ cycles of light and darkness. For each concentration of the chemical three replicates of 25 seeds were taken. Filter paper moistened with distilled water served as control. Germination percentage (GP) and seedling vigour (SV) were evaluated after 7 days by counting the seedlings and measuring the root and shoot lengths. The SV was expressed as Vigour Index (VI) of the seedlings which was calculated as (mean root length + mean shoot length) $\mathrm{x}$ (percentage germination).

\subsubsection{Germination Test in Soil}

Based on the results obtained from filter paper method, long-podded cowpea (V. unguiculata subsp. sesquipedalis), green gram (V. radiata) and chickpea ( $C$. arietinum), which showed high sensitivity to phenol, were selected for a secondary screening and detailed study in soil.

A red loamy type soil used in this study was collected from SIAS Campus, Vazhayoor East. The soil had a good water holding capacity and had $1.0-1.5 \%$ organic matter. The soil was sieved $(2 \mathrm{~mm})$ to remove debris and pebbles and autoclaved at $121^{\circ} \mathrm{C}$ for 20 minutes initially and then for 60 minutes after 2 days. 60 g each of soil (20\% moisture) was filled in alcohol-sterilized and dried plastic cups of $11 \mathrm{~cm}$ diameter and $4 \mathrm{~cm}$ depth. The required amount of phenol solution was added to the soil and mixed thoroughly to obtain uniform distribution. Phenol concentrations of 0,80 , 120 , and $160 \mathrm{mg} / \mathrm{kg}$ soil were used in the initial screening of the three seeds. Then, the most sensitive chickpea seeds were subjected to a further screening with a wider range of phenol concentration viz. $0,20,40,80$, 120,160 , and $200 \mathrm{mg} / \mathrm{kg}$ soil. Later, in the bioremediation studies 0,120 and $160 \mathrm{mg}$ phenol/g soil were used in the case of chickpea seeds. To the control ( 0 phenol) cups, equal amount of distilled water was added. The sides of the cups were pricked with a needle to enable aeration. Seeds (25 numbers) were placed in each cup at equal distance at a depth of $0.5 \mathrm{~cm}$ and three replicates were taken for each variable. The cups were incubated in a germinator at ambient temperature $\left(20-28{ }^{\circ} \mathrm{C}\right)$. Sterile distilled water $(5 \mathrm{~mL})$ was added to each cup every alternate day to maintain moisture. After 7 days, the GP and the VI were evaluated.

\subsection{Test of Viability of Chickpea Seeds Exposed to Phenol}

Normally living cells can take up 2,3,5-triphenyl-2H-tetrazolium chloride (TTC) and reduce it to a stable non-diffusing red pigment, 1,3,5triphenylformazan (TPF) through an oxidation-reduction reaction, which indicates mitochondrial respiration involving dehydrogenase enzyme and allows differentiation between normally stained and unstained or abnormally-stained tissue. The viability of chickpea seeds exposed and unexposed to phenol was tested using this principle by the method described in ISTA Rules 2009 [30].

https://doi.org/10.30799/jespr.199.20060201
Ten chickpea seeds were soaked for $24 \mathrm{~h}$ in aqueous solution of phenol of different concentrations (20 through $200 \mathrm{mg} / \mathrm{L}$ ). Same number of seeds soaked in distilled water served as control. The soaked seeds were cut along the margin to expose the embryo and placed in $0.1 \%$ aqueous solution of TTC for $24 \mathrm{~h}$ at $37{ }^{\circ} \mathrm{C}$ in darkness. The seeds were then removed, washed with distilled water, and soaked in $10 \mathrm{~mL}$ of $95 \%$ ethanol until the colour was completely extracted. The optical density of the extracted red colour was determined at $480 \mathrm{~nm}$ using Shimadzu UV1650 PC spectrophotometer.

\subsection{Enzyme Assays}

Protease and amylase activities in germinating chickpea seeds, both exposed to phenol (120 and $160 \mathrm{mg} / \mathrm{L}$ ) and unexposed control were assayed. Triplicate samples of 20 seeds/seedlings were collected every 24 $\mathrm{h}$ for 7 days and were ground with acid-washed sand for $15 \mathrm{~min}$ in a precooled mortar maintained on an ice-bath. The extract was prepared in 0.2 $\mathrm{M}$ acetate buffer ( $\mathrm{pH}$ 5.2), and the debris was removed by centrifugation at $10,000 \mathrm{rpm}$ for $10 \mathrm{~min}$ at $4{ }^{\circ} \mathrm{C}$ using REMI C-24BL centrifuge (Remi Electrotechnik Ltd., Vasai, India). The supernatant was made up to $5.0 \mathrm{~mL}$. This extract served as the crude enzyme for both protease and amylase assays.

A slightly modified method of Laskowsky [31] was followed for protease assay using bovine serum albumin (BSA) as substrate. To a solution of bovine serum albumin (BSA) $(10 \mathrm{mg} / \mathrm{mL})$ an equal volume of enzyme extract was added and incubated at $30^{\circ} \mathrm{C}$ for $30 \mathrm{~min}$. The enzyme activity was expressed as $\mathrm{OD}_{600}$ of the BSA hydrolysate obtained when reacted with Folin-Ciocalteau reagent. Amylase activity was assayed by measuring the release of reducing sugar from gelatinized soluble starch (1.0\% in $0.1 \mathrm{M}$ acetate buffer, pH 5.2) according to the method of Bernfeld [32].

\subsection{Bioremediation Studies}

The bacterial strain, $P$. aeruginosa S-CSR-0013 used in the study was capable of utilizing phenol as the sole carbon source, which was isolated earlier in the laboratory.

\subsubsection{Preparation of Bacterial Inoculum}

For the preparation of inoculum $P$. aeruginosa S-CSR-0013 was grown in shake flasks at $30{ }^{\circ} \mathrm{C}$ on a rotary shaker (200 rpm) in a mineral medium containing the following composition (g/L): $\mathrm{KH}_{2} \mathrm{PO}_{4}-2.72, \mathrm{Na}_{2} \mathrm{HPO}_{4}-3.52$ $\mathrm{NH}_{4}\left(\mathrm{SO}_{4}\right)_{2}-0.50$, yeast extract $-0.05, \mathrm{MgSO}_{4} .7 \mathrm{H}_{2} \mathrm{O}-0.20, \mathrm{Ca}\left(\mathrm{NO}_{3}\right)_{2}-0.10$ and one $\mathrm{mL}$ of trace mineral solution containing (g/L) $\mathrm{FeSO}_{4} .7 \mathrm{H}_{2} \mathrm{O}-1.00$ $\mathrm{MnSO}_{4} . \mathrm{H}_{2} \mathrm{O}-1.00, \mathrm{NaMoO}_{4} .2 \mathrm{H}_{2} \mathrm{O}-0.25, \mathrm{H}_{3} \mathrm{BO}_{3}-0.10, \mathrm{CuCl}_{2} .2 \mathrm{H}_{2} \mathrm{O}-0.25$ $\mathrm{NH}_{4} \mathrm{NO}_{3}-0.10, \mathrm{Ca}\left(\mathrm{NO}_{3}\right)_{2} .6 \mathrm{H}_{2} \mathrm{O}-0.25, \mathrm{NiSO}_{4} \cdot 6 \mathrm{H}_{2} \mathrm{O}-0.19$, Conc. $\mathrm{H}_{2} \mathrm{SO}_{4}-5 \mathrm{~mL}$. The $\mathrm{pH}$ of the medium was 7.2 before autoclaving. Phenol was added as the substrate at $500 \mathrm{mg} / \mathrm{L}$ level after cooling the medium and was inoculated with a loopful of cells from a culture slant. The bacterial cells growing at mid-exponential phase $(24 \mathrm{~h})$ were harvested by centrifugation at $10,000 \mathrm{rpm}$ for $10 \mathrm{~min}$ at $4{ }^{\circ} \mathrm{C}$. The cells were pooled and suspended in $50 \mathrm{~mL}$ of sterile water.

\subsubsection{Inoculation of Soil}

The thick cell suspension of $P$. aeruginosa S-CSR0013 cells prepared as above was used for inoculating the soil. Three $\mathrm{mL}$ of the cell suspension was added to $60 \mathrm{~g}$ of soil containing $20 \%$ moisture and different concentrations of phenol viz. 0,120 and $160 \mathrm{mg} / \mathrm{kg}$ soil taken in plastic cups and mixed thoroughly to ensure uniform distribution. The inoculum size was $246 \mathrm{mg}$ (wet cells)/cup to give an inoculum rate of $4.1 \mathrm{mg}$ (wet cells)/g soil. This amounted to a colony forming unit (CFU) count from 2.1 $\times 10^{7}$ to $2.8 \times 10^{7}$ cells/g soil.

Seeds were then sown and germinated at ambient temperature and the seedlings were evaluated for GP and SV after 7 days as described above in section 2.1.1. Soil without phenol was also inoculated to serve as a bacteria-augmented control. As the recovery from the phenol injury on germination was not fully achieved when the seeds were sown immediately after inoculating the soil with bacteria, the effect of sowing the seeds after 4 and 8 days after bacterial inoculation was also tried.

\subsubsection{Determination of Growth of Bacterium in Soil}

To determine the viability and the growth of the inoculated bacterial cells, one g samples of the soil was taken at $24 \mathrm{~h}$ intervals and suspended in $10 \mathrm{~mL}$ of sterile water and shaken in a Vortex mixer. The bacterial suspension was appropriately diluted and $0.1 \mathrm{~mL}$ of bacterial suspension was spread on nutrient agar plates. The plates were incubated at $30{ }^{\circ} \mathrm{C}$ for 24-48 h. The colonies were counted using a colony counter and the growth was expressed as CFU. 


\subsection{Estimation of Phenol}

A modified 4-aminoantipyrene colorimetric method based on Lacoste et al. [33] was followed for estimation of residual phenol in spiked and bacterially amended and un-amended soils. One-gram soil was collected from each cup at $24 \mathrm{~h}$ intervals and extracted in $5 \mathrm{~mL}$ distilled water by mixing gently, to avoid extraction of soil colour.

Phenol in this sample was estimated as follows: To $10 \mathrm{~mL}$ of appropriately diluted sample $0.5 \mathrm{~mL}$ of borate buffer, $0.1 \mathrm{~mL}$ of $1.5 \% 4$ aminoantipyrene and $0.1 \mathrm{~mL}$ of $10 \%$ potassium ferricyanide $\left(\mathrm{K}_{3} \mathrm{Fe}\left(\mathrm{CN}_{6}\right)\right)$ solutions were added. (Borate buffer was prepared by dissolving $6.2 \mathrm{~g}$ boric acid and $7.0 \mathrm{~g}$ of $\mathrm{KCl}$ in $800 \mathrm{~mL}$ of distilled water to which was added 64 mLof $1 \mathrm{~N} \mathrm{NaOH}$ and made up to one litre). The colour developed was measured at $506 \mathrm{~nm}$ using Shimadzu UV-1650 PC spectrophotometer. Results were computed from a standard calibration curve prepared using varying concentrations of phenol.

\subsection{Statistical Analysis of Data}

The Dunken Multiple Range Test (DMRT) was used to determine means, which differed significantly at $\mathrm{P}<0.05$ to analyse the Vigour Index data.

\section{Results and Discussion}

\subsection{Screening of Crop Seeds for Sensitivity to Phenol}

Phenol being an industrial chemical the possibility of its seepage to cultivating fields from waste dumpsites as well as from industrial wastes disposed without proper treatment cannot be ruled out. It was with this background the present study was conducted to evaluate the effect of phenol on various crop seeds and, if found deleterious, how to eliminate it.

\subsubsection{Filter Paper Method}

Among the 11 seeds tested on filter paper phenol had no apparent adverse effect on the germination of brinjal (eggplant), tomato, maize, pumpkin, lady's finger, red chilli, spinach, and cucumber seeds up to a concentration of $800 \mathrm{mg} / \mathrm{L}$. There was no reduction in GP as compared to the control sets of the respective seeds. However, three seeds, chickpea ( $C$. arietinum), mung bean or green gram ( $V$. radiata), and long-podded cowpea (V. unguiculata subsp. sesquipedalis) were found to be very sensitive to phenol. In Fig. 1 is shown the results of germination and seedling growth of these seeds at $0,400,600$, and $800 \mathrm{mg}$ phenol/L in petri plates $1,2,3$, and 4, respectively. As could be seen chickpea (C. arietinum) seeds were the most sensitive as the germination was totally inhibited at $400 \mathrm{mg} / \mathrm{L}$ of phenol whereas mung bean, and long-podded cowpea seeds exhibited partial germination at this concentration albeit with stunted growth of both roots and shoots (Fig. 1). As there was no germination at all at higher concentrations, they are not included in Fig. 1.

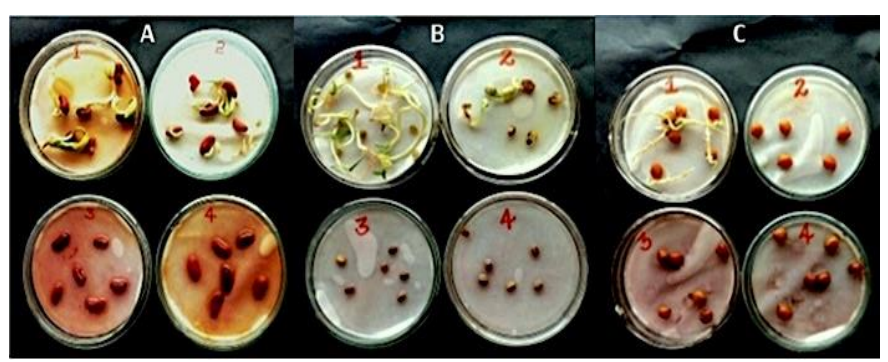

Fig. 1 Effect of different concentrations of phenol on germination of long-podded cowpea (A), mung bean (B), and chickpea (C) seeds as tested by filter paper method [29]. Numbers $1,2,3$, and 4 on the petri plates indicate the phenol concentrations 0 (control), 400, 600, and $800 \mathrm{mg} / \mathrm{L}$

It is interesting to note that the susceptibility of seeds of plants belonging to a particular family is more than that of others i.e. all the seeds that got affected by phenol in the present study belonged to the family Fabaceae. Similar responses of family specific susceptibility to other toxic compounds also have been reported earlier.

Ajithkumar et al. [22] have reported that among the various crop seeds tested seeds of Solanaceae members such as tomato, eggplant, and tobacco were highly susceptible to 3-CBA and 4-CBA. They found that exposure of tomato seeds to $400 \mathrm{mg}$ of 3-CBA)/4-CBA/ $\mathrm{kg}$ soil a complete inhibition of germination occurred and a marked reduction in VI was observed even at lower concentrations. Gangadhara and Kunhi [23] also have reported a similar phenomenon where 2,4,5-T was found to be highly inhibitory to the seeds of eggplant and tomato (both belonging to Solanaceae family) than other seeds tested.

https://doi.org/10.30799/jespr.199.20060201

\subsubsection{Soil Method}

The seeds of long-podded cowpea, mung bean and chickpea, which showed high sensitivity to phenol when tested on filter paper, were selected for a secondary screening and a detailed study in soil. These seeds were treated with $0,80,120$, and $160 \mathrm{mg}$ of phenol/kg soil. Reduction in GP and VI, in varying degrees, was observed by soil method too. The data on the effect of phenol on GP and VI of these three seeds at $0,80,120$, and $160 \mathrm{mg}$ phenol/kg soil are shown in Table 1 . The sensitivity of these seeds towards phenol was in the order chickpea $>$ green gram $>$ long-podded cowpea. In the case of long-podded cowpea, $80 \mathrm{mg} / \mathrm{kg}$ phenol did not cause any marked reduction in GP (98\% as against $99 \%$ in control seeds), but the VI was reduced by 20\% (485 as against 602). At higher concentrations (120 and $160 \mathrm{mg} / \mathrm{kg}$ soil), however, both the GP and VI were reduced considerably i.e. to 50 and $40 \%$, and 19.92 and $14.81 \%$, respectively as compared to that of control (Table 1). In the case of green gram, the VI was reduced to almost 44,22 , and $8 \%$ while the GP was reduced to 50,30 , and $20 \%$ at 80,120 and $160 \mathrm{mg}$ phenol/kg soil respectively (Table 1). C. arietinum seeds exposed to phenol exhibited drastic reduction in GP and VI. GP at 80,120 , and $160 \mathrm{mg} / \mathrm{kg}$ soil were 36 , 24 and $8 \%$ as against $99 \%$ in the case of control and VI values were 26.1 , 7.47 , and $1.29 \%$ of that of control seeds, respectively (Table 1).

Table 1 Effect of different concentrations of phenol on seed germination and seedling vigour

\begin{tabular}{llllr}
\hline Phenol (mg/kg soil) & Germ.\% & MSL with SD & MRL with SD & \multicolumn{1}{c}{ VI $^{*}$} \\
\hline Long-Podded Cowpea & & & & \\
\hline 0 & 99 & $4.28 \pm 0.0328$ & $1.74 \pm 0.231$ & $602.0^{\mathrm{a}}$ \\
80 & 98 & $3.81 \pm 0.1830$ & $1.04 \pm 0.078$ & $485.0^{\mathrm{b}}$ \\
120 & 50 & $2.38 \pm 0.1460$ & $0.94 \pm 0.019$ & $119.9^{\mathrm{c}}$ \\
160 & 40 & $1.48 \pm 0.0870$ & $0.75 \pm 0.031$ & $89.2^{\mathrm{d}}$ \\
SEM & & \pm 0.02 & \pm 0.01 & \\
\hline Mung Bean & & & & \\
\hline 0 & 98 & $5.25 \pm 0.139$ & $2.21 \pm 0.159$ & $746.0^{\mathrm{a}}$ \\
80 & 50 & $5.08 \pm 0.127$ & $1.45 \pm 0.128$ & $326.5^{\mathrm{b}}$ \\
120 & 30 & $4.50 \pm 0.142$ & $1.09 \pm 0.051$ & $167.7^{\mathrm{c}}$ \\
160 & 20 & $2.06 \pm 0.230$ & $0.94 \pm 0.019$ & $60.0^{\mathrm{d}}$ \\
SEM & & \pm 0.03 & \pm 0.01 & \\
\hline Chickpea & & & & \\
\hline 0 & 99 & $6.77 \pm 0.374$ & $3.19 \pm 0.241$ & $996.0^{\mathrm{a}}$ \\
80 & 36 & $5.05 \pm 0.174$ & $2.16 \pm 0.092$ & $259.5^{\mathrm{b}}$ \\
120 & 24 & $2.02 \pm 0.104$ & $1.08 \pm 0.003$ & $74.4^{\mathrm{c}}$ \\
160 & 8 & $0.94 \pm 0.106$ & $0.67 \pm 0.008$ & $12.8^{\mathrm{d}}$ \\
SEM & & \pm 0.03 & \pm 0.01 & \\
\hline
\end{tabular}

${ }^{*}$ Vigour Index $=$ (mean root length + mean shoot length) $x$ (percent germination). DMRT was used to determine means, which differ significantly at $P<0.05$. In each column values with similar letters do not differ significantly at the $5 \%$ level

As chickpea seeds showed highest sensitivity to phenol, the soil test was repeated by treating with a wider range of phenol concentration viz. 20 $40,80,120,160$, and $200 \mathrm{mg} / \mathrm{kg}$ soil. As could be seen from Table 2 as well as from Fig. 2, even at a concentration as low as $40 \mathrm{mg}$ phenol $/ \mathrm{kg}$ soil there was a marked reduction in GP and VI. At $200 \mathrm{mg} / \mathrm{kg}$ the VI fell almost to zero level (Table 2). Abnormalities of seedlings were also observed as a result of exposure to phenol (Fig. 2). The root and shoot lengths were considerably reduced. Moreover, the seedlings showed primary root inhibition. At 160 and $200 \mathrm{mg} / \mathrm{kg}$ shoots were not formed at all. The seedlings showed negatively geotropic growth and primary root inhibition. Blackening of seedlings was also observed in some cases. In many seeds the primary leaves did not emerge out of the seed coat. In the case of seeds of long-podded cowpea and green gram also the abnormalities were more or less of the same nature (Fig. 1). Similar abnormalities have also been reported earlier in the case of seeds exposed to 3-CBA and 4-CBA [22] and those exposed to 2,4,5-T [23].

Table 2 Effect of different concentrations of phenol on germination and seedling vigour of chickpea seeds as tested by soil method

\begin{tabular}{lllll}
\hline Phenol (mg/kg soil) & Germ.\% & MSL with SD & MRL with SD & VI* $^{*}$ \\
\hline 0 & 99 & $7.30 \pm 0.071$ & $4.03 \pm 0.05$ & $1133.00^{\mathrm{a}}$ \\
20 & 92 & $6.66 \pm 0.070$ & $3.20 \pm 0.24$ & $907.12^{\mathrm{a}}$ \\
40 & 80 & $5.22 \pm 0.020$ & $3.18 \pm 0.016$ & $672.00^{\mathrm{b}}$ \\
80 & 40 & $3.40 \pm 0.020$ & $1.42 \pm 0.014$ & $192.80^{\mathrm{c}}$ \\
120 & 32 & $1.94 \pm 0.007$ & $1.08 \pm 0.006$ & $96.64 \mathrm{~d}^{\mathrm{d}}$ \\
160 & 16 & $1.10 \pm 0.007$ & $0.84 \pm 0.01$ & $31.04 \mathrm{e}$ \\
200 & 8 & $0.32 \pm 0.320$ & $0 \pm 0$ & $2.56^{\mathrm{f}}$ \\
SEM & & \pm 0.01 & \pm 0.0096 & \\
\hline
\end{tabular}

*Vigour Index $=($ mean root length + mean shoot length $) x$ (percent germination). DMRT was used to determine means, which differ significantly at $P<0.05$. In each column values with similar letters do not differ significantly at the $5 \%$ level 
A

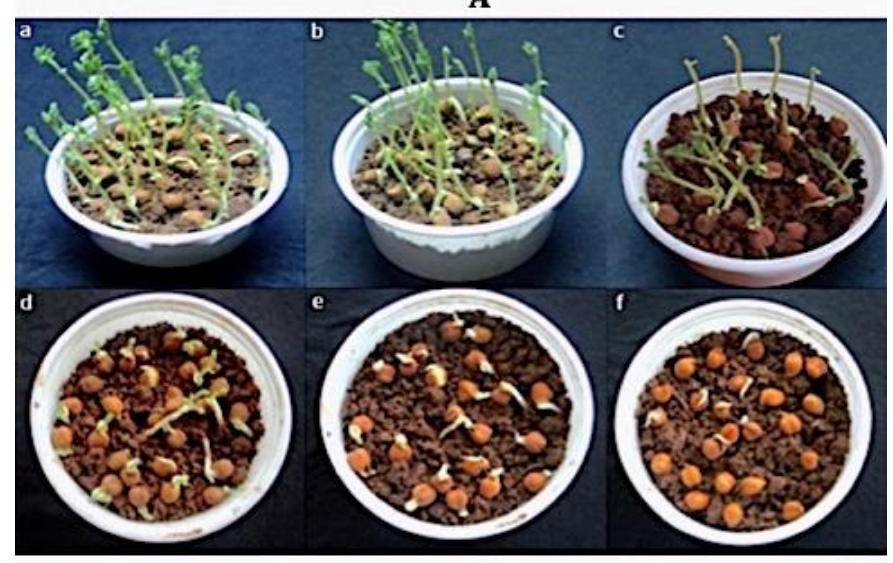

$\mathbf{B}$

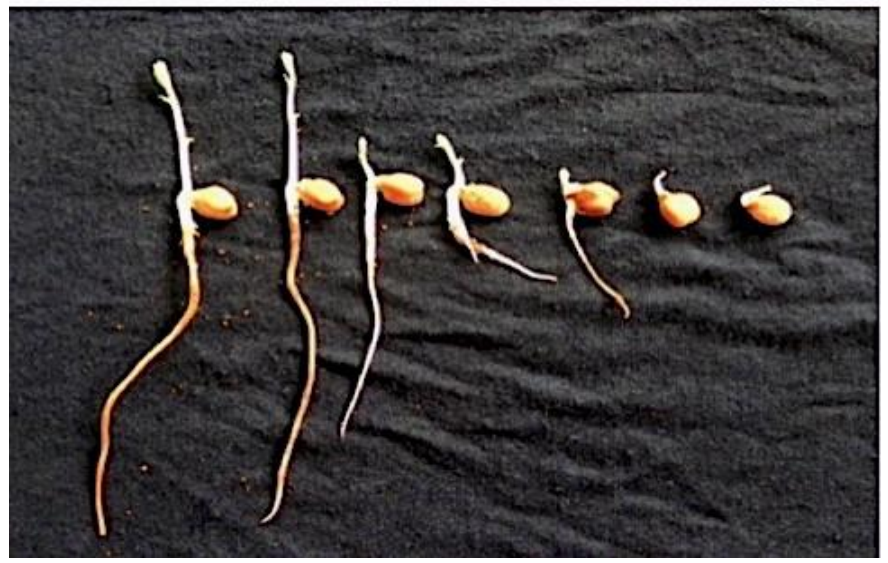

Fig. 2 Effect of different concentrations of phenol on seed germination and seedling vigour of chickpea. Plate (A) Germination and growth of seedlings of chickpea at phenol concentrations (a) 0, (b) 20, (c) 40, (d) 8), (e) 160, and (f) $200 \mathrm{mg} / \mathrm{kg}$ soil. Plate (B) (from left to right) Single representative seedling formed in the presence of $0,20,40,80,120,160$, and $200 \mathrm{mg}$ phenol $/ \mathrm{kg}$ soil, respectively

As mentioned in the introduction, phytotoxic allelopathic interactions in field soils or in water are caused by mainly by phenolics and humic acids $[6,7,15]$. Phytotoxicity caused by olive mill wastewater and dry olive residue was also shown to be due to low molecular weight phenols present in them [8-10]. Long-term cultivation of lemon balm (Melissa officinalis L.) was shown to accumulate phenolic compounds in the soil and exert phytotoxic effects on the growth and the essential oil yield [34]. Inhibition of germination of tomato and chicory seeds by olive mill wastewater was shown to be due to the phenolic substances present therein [35]. Yu and Matsui [36] have reported that the phytotoxic chemicals accumulated in the nutrient solution during hydroponic cultivation of tomato were benzoic, 4-hydroxybenzoic, phenyl acetic, vanillic, ferulic, caffeic, 2hydroxy-3-phenylpropionic, phthalic, sinapic, and palmitic acids. Inhibition of seedling development (i.e., reduced root and shoot growth) and reduction in GP of tall fescue exposed to up to $30 \mathrm{mg} 2,4,6-$ trinitrotoluene (TNT)/L or higher concentrations and $15 \mathrm{mg}$ 4-amino-2,6dinitrotoluene(4ADNT)/L was observed by Peterson et al. [37].

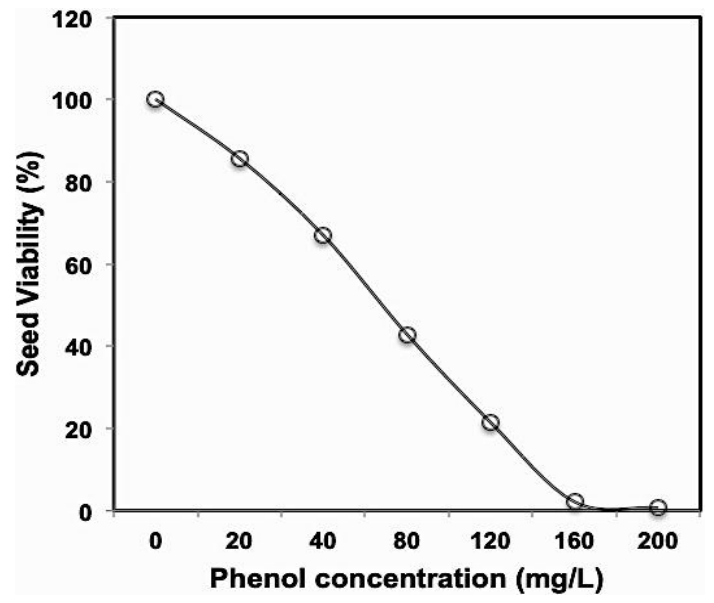

Fig. 3 Effect of different concentrations of phenol on the viability of chickpea seeds as assessed by 2,3,5-triphenyl tetrazolium chloride (TTC) test [30] https://doi.org/10.30799/jespr.199.20060201

\subsection{Viability of Seeds of C. arietinum on Exposure to Phenol}

The standard TTC test [30] indicated a gradual decrease in viability of C. arietinum seeds proportional to the concentration of phenol (from 0 through $200 \mathrm{mg} / \mathrm{L}$ ) they were exposed to. At $160 \mathrm{mg} / \mathrm{L}$ very low and at $200 \mathrm{mg} / \mathrm{L}$ phenol almost zero viability was observed. The results are depicted in Fig. 3. It could be inferred that phenol inhibits the activity of dehydrogenases that catalyze mitochondrial respiration, thus rendering the seeds non-viable. Similar observation was made in the case of tomato seeds exposed to 3-CBA/4-CBA [22] and 2,4,5-T [23] and tall fescue exposed to TNT and 4ADNT [37].

\subsection{Effect of Phenol on the Enzyme Activities of Germinating Chickpea Seeds}

Imbibition of water by seeds normally triggers various metabolic processes such as synthesis of hydrolytic enzymes, which results in hydrolysis of reserve food into simple available form for embryo uptake [38]. Proteases and amylases are generally involved in the mobilization of the stored nutrients in seed kernels during germination and an increase in these and other enzymatic activities are generally observed [38, 39]. Hence, it was envisaged that determination of these enzyme activities would provide some insight into the mechanism of inhibition of germination by phenol. Induction of both amylase and protease was drastically affected on exposure to phenol, more severely so by the higher concentration of $160 \mathrm{mg} / \mathrm{kg}$ soil whereas the seeds germinating in the absence of the chemical showed fairly good activities (Figs. 4 and 5). In the control seeds there was a steep increase in amylase activity up to day 3 after sowing the seeds, which started declining gradually then onwards reaching zero level on day 7 (Fig. 4). In the case of seeds germinated in the presence of $120 \mathrm{mg}$ phenol/kg amylase activity was much lower and started declining after 2 days and touched zero level on day 5. At 160 $\mathrm{mg} / \mathrm{kg}$ soil there was only negligible amylase activity. The amylase activity obtained in the case of seeds exposed to 120 and $160 \mathrm{mg}$ phenol/kg soil was 44.4 , and $2.2 \%$, respectively as compared to that of control seeds.

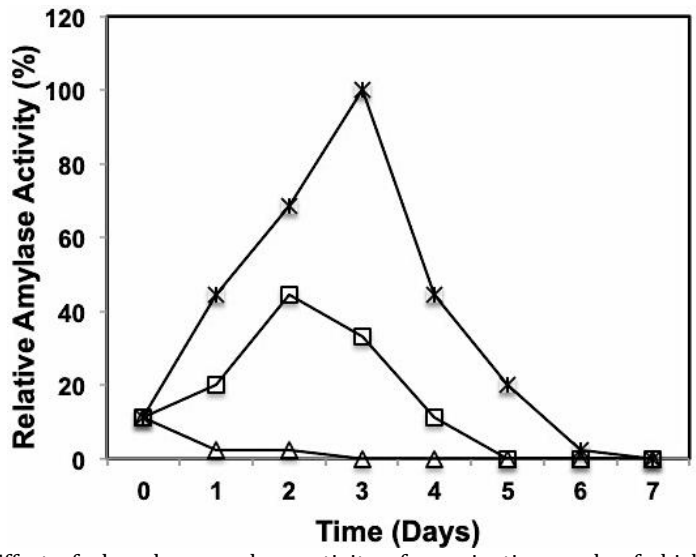

Fig. 4 Effect of phenol on amylase activity of germinating seeds of chickpea (-xcontrol (without phenol), $-\square-120$, and $-\Delta-160 \mathrm{mg} / \mathrm{L}$ of phenol). Lines are plotted taking maximum activity obtained for control seeds as $100 \%$

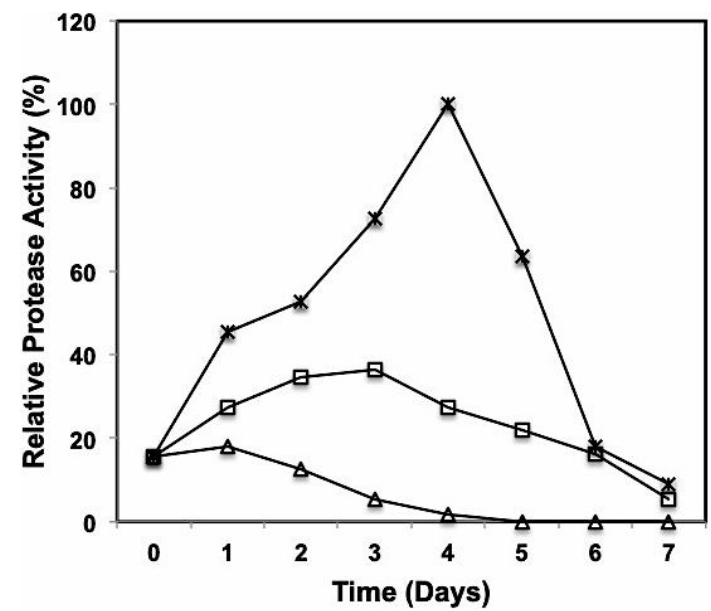

Fig. 5 Effect of phenol on protease activity of germinating seeds of chickpea (-xcontrol (without phenol), $-\square-120$, and $-\Delta-160 \mathrm{mg} / \mathrm{L}$ of phenol). Lines are plotted taking maximum activity obtained for control seeds as $100 \%$

The seeds exposed to phenol also showed marked reduction in the protease activity, the reduction being more pronounced with higher concentration (Fig. 5). The pattern was similar to that of amylase, but the 
increase in activity continued till day 4 after sowing and started declining thereafter, reaching a minimum on day 7 , in the case of control seeds. Protease activity of the phenol-exposed seeds (120 and $160 \mathrm{mg} / \mathrm{kg}$ soil) was only 36.36 and $12.73 \%$, respectively of that of control seeds. However, the interference of phenol on protease activity was not as severe as that on the amylase activity. In similar studies it was shown that 3-CBA and 4CBA [22] and 2,4,5-T [23] also deleteriously affected these enzymes in germinating tomato seeds. Reduced protease and amylase activities have also been reported in radish and green gram seeds sown in soil spiked with tech-HCH [20]. All these chemicals including phenol seem to interfere with the activities of most of the nutrient mobilising enzymes as well as the mitochondrial dehydrogenase.

\subsection{Bioaugmentation of Soil with P. aeruginosa S-CSR-0013 and Protection of Seed Germination}

It has been established that bioremediation is an effective method of elimination of toxic chemicals from polluted sites [24, 25]. One of the strategies adopted has been bioremediation through cell augmentation using microorganisms possessing degrading potentials, and studies have indicated the possibility of successful application of such processes [24, 25]. Phenol being a priority pollutant a lot of work has been done on its elimination from contaminated sites and industrial wastes deploying bacterial, fungal and algal cultures [26-28, 40].

The present study augmented the phenol-spiked soil with a phenoldegrading bacterial strain, $P$. aeruginosa S-CSR-0013. In the cups containing phenol both at 120 and $160 \mathrm{mg} / \mathrm{kg}$ soil the seeds sown after 8 days exhibited good germination with normal GP and VI (Table 3). Wang et al. [11] have shown that inoculation of P. aeruginosa SZH16 in to phenolspiked soil resulted in in situ phenol degradation and promotion of corn plant growth. They demonstrated that the increase in plant biomass correlated with the decrease in phenol content in the soil. A Pseudomonas stutzeri strain possessing a self-transmissible TOL-like plasmid was shown to degrade phenol and promote growth of maize plant in contaminated environments [12]. Mrozik et al. [41] have reported enhancement of degradation of high concentration of phenol from soil by augmentation of soil with Pseudomonas sp. JS150.

Table 3 Effect of bioaugmentation of phenol-spiked soil with Pseudomonas aeruginosa S-CSR-0013 cells on germination and seedling vigour of chickpea seeds

\begin{tabular}{|c|c|c|c|c|}
\hline Phenol (mg/kg soil) & Germ. $\%$ & MSL with SD & MRL with SD & VI* \\
\hline \multicolumn{5}{|l|}{ Immediate (0 day) } \\
\hline$\overline{0}$ & 100 & $6.50 \pm 0.011$ & $5.00 \pm 0.030$ & $1150.0^{\mathrm{a}}$ \\
\hline 12 & 50 & $2.96 \pm 0.011$ & $1.93 \pm 0.009$ & $244.5^{b}$ \\
\hline 160 & 36 & $1.52 \pm 0.014$ & $0.84 \pm 0.010$ & $85.0^{c}$ \\
\hline SEM & & \pm 0.0024 & \pm 0.0032 & \\
\hline $0+B I$ & 100 & $6.90 \pm 0.012$ & $4.70 \pm 0.112$ & $1160.0^{a}$ \\
\hline $120+B I$ & 88 & $4.44 \pm 0.132$ & $3.16 \pm 0.019$ & $668.8^{b}$ \\
\hline $160+\mathrm{BI}$ & 72 & $2.02 \pm 0.002$ & $1.86 \pm 0.008$ & $279.4^{c}$ \\
\hline SEM & & \pm 0.0097 & \pm 0.0092 & \\
\hline \multicolumn{5}{|l|}{ After 4 days } \\
\hline$\overline{0}$ & 100 & $6.80 \pm 0.116$ & $4.80 \pm 0.091$ & $1160.0^{\mathrm{a}}$ \\
\hline 120 & 60 & $3.00 \pm 0.111$ & $1.99 \pm 0.002$ & $299.4^{b}$ \\
\hline 160 & 35 & $1.65 \pm 0.191$ & $0.80 \pm 0.112$ & $85.8^{\mathrm{c}}$ \\
\hline SEM & & \pm 0.02 & \pm 0.01 & \\
\hline $0+\mathrm{BI}$ & 100 & $6.90 \pm 0.019$ & $4.90 \pm 0.119$ & $1180.0^{a}$ \\
\hline $120+B I$ & 85 & $5.30 \pm 0.122$ & $3.10 \pm 0.112$ & $714.0^{\mathrm{b}}$ \\
\hline $160+B I$ & 85 & $6.00 \pm 0.121$ & $3.90 \pm 0.040$ & $841.5^{c}$ \\
\hline SEM & & \pm 0.01 & \pm 0.01 & \\
\hline \multicolumn{5}{|l|}{ After 8 days } \\
\hline 0 & 100 & $6.90 \pm 0.099$ & $4.80 \pm 0.114$ & $1170.0^{\mathrm{a}}$ \\
\hline 120 & 45 & $4.20 \pm 0.110$ & $3.00 \pm 0.248$ & $324.0^{\mathrm{b}}$ \\
\hline 160 & 35 & $1.75 \pm 0.117$ & $0.90 \pm 0.113$ & $89.6^{c}$ \\
\hline SEM & & \pm 0.02 & \pm 0.03 & \\
\hline $0+\mathrm{BI}$ & 100 & $6.80 \pm 0.113$ & $5.00 \pm 0.102$ & $1180.0^{\mathrm{a}}$ \\
\hline $120+B I$ & 92 & $6.75 \pm 0.211$ & $5.00 \pm 0.148$ & $1175.0^{a}$ \\
\hline $160+B I$ & 98 & $6.90 \pm 0.213$ & $4.50 \pm 0.119$ & $1172.0^{a}$ \\
\hline SEM & & \pm 0.03 & \pm 0.02 & \\
\hline
\end{tabular}

$\overline{B I-I n o c u l a t e d ~ w i t h ~ b a c t e r i a l ~ c e l l s ; ~ * V i g o u r ~ I n d e x ~}=($ mean root length + mean shoot length) $x$ (percent germination). DMRT was used to determine means, which differ significantly at $P<0.05$. In each column values with similar letters do not differ significantly at the $5 \%$ level

There are also a few reports on elimination of the inhibitory effect of other organic compounds by bacterial amendment of contaminated soil and normalization of seed germination. Ajithkumar et al. [22] have demonstrated the elimination of deleterious effects of 3-CBA and 4-CBA on germination of tomato seeds through inoculation of the spiked soil with $P$. aeruginosa $3 \mathrm{mT}$. In a similar study Gangadhara and Kunhi [23] have https://doi.org/10.30799/jespr.199.20060201 shown that bioaugmentation of the 2,4,5-T-spiked soil with B. cepacia AC1100 completely protected the germination of tomato seeds. Bioaugmentation of HCH-contaminated soil with a microbial consortium and elimination of the inhibitory effects of the insecticide on seed germination of radish and green gram has also been reported [20].

It could be noted in Table 3 that in the cups in which the seeds were sown immediately or after 4 days of bacterial inoculation full recovery of GP and VI was not achieved. This was, probably, because the phenol concentration was not brought down to the safer level in these cases. Use of a higher inoculum size may, probably, expedite the degradation of phenol thus making it possible to bioremediate at a faster rate and render the soil suitable for sowing the seeds. This, however, needs to be experimentally verified. Gangadhara and Kunhi [23] have made a similar observation in the case of bioremediation of 2,4,5-T-spiked soil by $B$ cepacia AC1100. It was shown that seeds sown immediately or after 3 days of bacterial inoculation did not show proper germination whereas the seeds sown after 7 days, the germination was normal. Ajithkumar et al [22], on the other hand, have reported that the seeds germinated normally even when the seeds were sown immediately after inoculation of 3CBA/4-CBA-spiked soil with $P$. aeruginosa $3 \mathrm{mT}$. In soil, bio-remediated with strain $3 \mathrm{mT}$, normal GP and VI of tomato was observed even with an inoculum density of $1 \mathrm{pg}$ cells (dry weight)/g soil. It was possible that the chemicals were degraded effectively at a faster rate by the inoculated bacterium before the seed germination process began. Similarly, Krueger et al. [17] have shown protection of soybean and pea seedlings from the deleterious effects of the herbicide dicamba by inoculating soils with dicamba-degrading bacteria rendering normal germination of seeds, irrespective of the time of sowing.

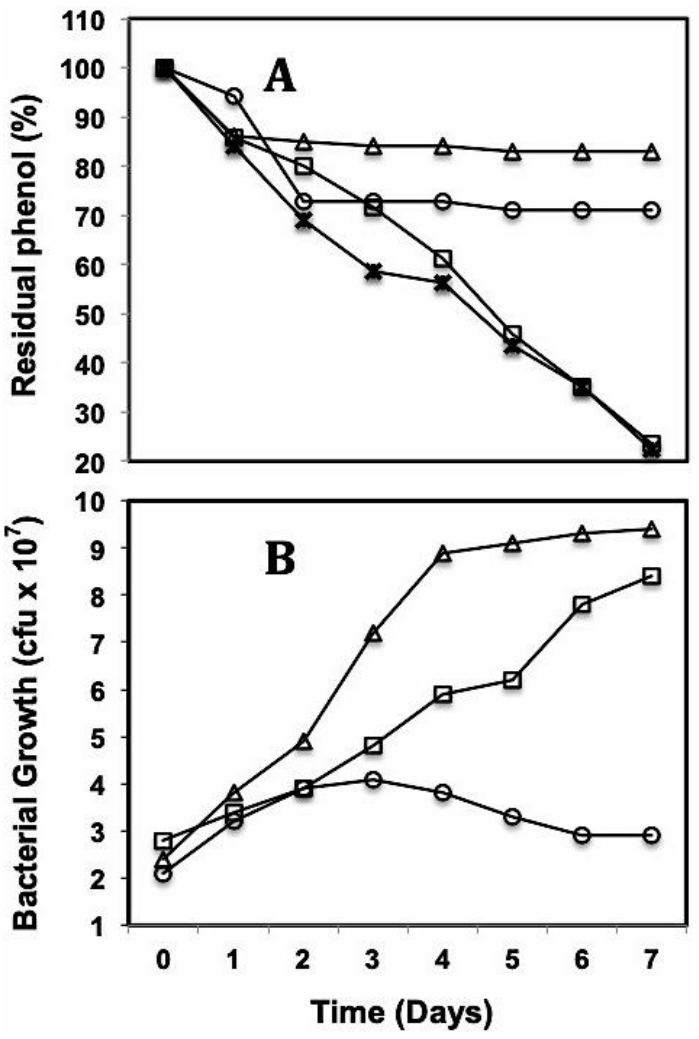

Fig. 6 Degradation of phenol $(\mathrm{A})$ and growth of the inoculated Pseudomonas aeruginosa S-CSR-0013 (B) in soil spiked with phenol. (A) $120 \mathrm{mg}$ phenol $/ \mathrm{kg}$ soil $\left(-0^{-}\right)$and $160 \mathrm{mg}$ phenol/kg soil $(-\Delta-)$ both without bacterial inoculum and 120 $\mathrm{mg} / \mathrm{kg}$ soil (- $\square-$ ) and $160 \mathrm{mg} / \mathrm{kg}$ soil (-x-) both inoculated with bacterial cells. (B) Bacterial growth in soil spiked with $0\left(-\mathrm{o}^{-}\right), 120$ (- $\left.\square-\right)$, and $160(-\Delta-) \mathrm{mg}$ phenol/kg soil

The phenol degrading efficiency of the inoculated bacterium was monitored through estimation of residual phenol in the soil. A gradual decrease in residual phenol was observed in the phenol-spiked soil inoculated with $P$. aeruginosa S-CSR-0013 (Fig. 6A). Degradation of about $80 \%$ of phenol from the soils spiked with both 120 and $160 \mathrm{mg} / \mathrm{kg}$ soil occurred within 7 days of incubation after the inoculation of the bacterium. The disappearance of about $20-25 \%$ of the added phenol from the un-inoculated soils (Fig. 6A) might have been due to partial evaporation and/or binding to the soil particles.

The inoculated P. aeruginosa S-CSR-0013 not only survived in the soil but also exhibited an increase in cell population in phenol-spiked soil (Fig. 6B). In soil containing both 120 and $160 \mathrm{mg}$ phenol/kg soil, there was a 
steady increase in growth of the organism up to day 7 , the growth being, from an initial CFU/g soil of $2.8 \times 10^{7}$ to $8.4 \times 10^{7}$ and $2.4 \times 10^{7}$ to $9.4 \times 10^{7}$ in soil containing 120 and $160 \mathrm{mg}$ of phenol/ $\mathrm{kg}$, respectively. The bacterial growth was concomitant with the reduction in phenol concentration indicating its efficient utilisation by the bacterium. In control soil without phenol there was a marginal increase in cell density (from $2.1 \times 10^{7}$ to 4.1 $\times 10^{7} \mathrm{CFU} / \mathrm{g}$ soil) up to 3 days, beyond which the cell number started dwindling. This slight growth would have occurred, probably, by utilizing the small amounts of organic matter and other nutrients present in the soil. As could be observed in Table 3, a slight increase in VI was observed in the bacterium-inoculated soil as compared to that of the un-inoculated control, irrespective of whether they contained phenol or not. Other workers also have made similar observations in soils inoculated with $P$. aeruginosa $3 \mathrm{mT} \mathrm{[22]} \mathrm{and} \mathrm{B.} \mathrm{cepacia} \mathrm{AC1100} \mathrm{[23],} \mathrm{respectively.} \mathrm{However,}$ in the absence of experimental evidence it is difficult to explain the exact reason why it is happening. It could be due to the production and secretion of some growth-promoting factor(s) by the inoculated strain or could be due to the destruction of any growth-inhibiting substance present in the soil. It has been shown that free-living nitrogen-fixing bacteria or associative nitrogen fixers viz. bacteria belonging to the genus Azospirillum, Enterobacter, Klebsiella and Pseudomonas, could be used for improving soil fertility and suppressing plant diseases [42,43].

\section{Conclusion}

The inhibitory effect of phenol on the germination of certain crop seeds, particularly those of chickpea, mung bean, and long-podded cowpea, and its deleterious effect on seedling vigour have been established. The study showed that the seeds of Fabaceae members are particularly sensitive to phenol. It has also been shown that these harmful effects, particularly on chickpea seeds, can efficiently be eliminated by bioaugmentation of phenol-spiked soil by inoculating with $P$. aeruginosa S-CSR-0013. However, the data presented here pertain to laboratory studies, and detailed field trials have to be carried out to validate the findings and to ascertain the suitability of this bioremediation technique in phenol contaminated soils under natural conditions.

\section{Acknowledgements}

The authors would like to thank the Governing Board of SIAS, Vazhayoor East and the members of Social Advancement Foundation of India (SAFI) for providing the facilities, their continued support for the study, and the permission for publishing the data. We are also thankful to N.K. Shainy for kindly donating the $P$. aeruginosa strain used in this study.

\section{References}

[1] https://www.researchandmarkets.com/research/t8tnsk/global_phenols? 2018. (Accessed on $5^{\text {th }}$ December 2018)

[2] M. Weber, M. Weber, Phenols. in: L. Pilato (Ed.), Phenolic resins: A century of progress, Springer-Verlag Berlin Heidelberg, Germany, 2010, pp.9-23.

[3] B.E. Rittmann, P.L. McCarty, Environmental biotechnology: Principles and applications, McGraw-Hill, New York, 2001.

[4] I. Rodriguez, M.P. Liompart, R. Cela, Solid-phase extraction of phenols, J. Chromatogr. A 885 (2000) 291-304.

[5] S. Ren, P.D. Frymier, Toxicity estimation of phenolic compounds by bioluminescent bacterium, J. Environ. Eng. (ASCE) 129 (2003) 328-335.

[6] Inderjit, K.M.M. Dakshini, C.L. Foy, (Eds.), Principles and practices in plant ecology: Allelochemical interactions, CRC Press, 1999.

[7] U. Blum, Plant-plant allelopathic interactions: Phenolic acids, cover crops and weed emergence, Springer Science \& Business Media BV, Switzerland, 2011.

[8] M. DellaGreca, P. Monaco, G. Pinto, A. Pollio, L. Previtera, F. Temussi, Phytotoxicity of low-molecular-weight phenols from olive mill wastewaters, Bull. Environ Contam. Toxicol. 67 (2001) 352-359.

[9] A. Fiorentino, A. Gentili, M. Isidori, P. Monaco, A. Nardelli, et al., Environmental effects caused by olive mill wastewaters: toxicity comparison of lowmolecular-weight phenol components, J. Agric. Food Chem. 51 (2003) 10051009.

[10] M. Isidori, M. Lavorgna, A. Nardelli, A. Parella, Model study on the effect of 15 phenolic olive mill wastewater constituents on seed germination and Vibrio fischeri metabolism, J. Agric. Food Chem. 53 (2005) 8414-8417.

[11] Y. Wang, J. Song, W. Zhao, X. He, J. Chen, M. Xiao, In situ degradation of phenol and promotion of plant growth in contaminated environments by a single Pseudomonas aeruginosa strain, J. Hazar. Mater. 192 (2011) 354-360.

[12] Q. Jiang, C. Zhou, Y. Wang, F. Si, Y. Zhou, et al., Pseudomonas stutzeri strain possessing a self-transmissible TOL-like plasmid degrades phenol and promotes maize growth in contaminated environments, Appl. Biochem. Biotechnol. 172 (2014) 346-3475.

[13] K. Poon, K.L. Hon, J.J. Huang, The phytotoxicity of 2,4,6-trichlorophenol and phenol to local agricultural plant species in China, in: V. Popov, C.A. Brebbia
(Eds.), Food and Environment: The quest for a sustainable future, WIT Trans. Ecol. Environ. 152 (2011) 203-213.

[14] A.S. Ucisik, S. Trapp, Uptake, removal, accumulation, and phytotoxicity of phenol in willow trees (Salix viminalis), Environ. Toxicol. Chem. 25 (2006) 2455-2460.

[15] Yukiko, K. Yasuo, T. Minoru, Effects of phenolic compounds on seed germination of shirakamba birch Betula platyphylla var. japonica, Eurasian J. Forest Res. 2 (2001) 17-25.

[16] Z.D. Lancaster, J.K. Norsworthy, R.C. Scott, Residual activity of ACCaseinhibiting herbicides on monocot crops and weeds, Weed Technol. 32(4) (2018) 364-370.

[17] J.P. Krueger, R.G. Butz, D.J. Cork, Use of dicamba-degrading microorganisms to protect dicamba susceptible plant species, J. Agric. Food Chem. 39 (1991) 1000-1003.

[18] D.E. Moreland, Effect of herbicides on seed germination, Rev. Plant Physiol. 18 (1967) 356-386.

[19] E. Grabińska-Sota, E. Wiśniowska, J. Kalka, Toxicity of selected synthetic auxines, 2,4-D and MCPA derivatives to broad-leaved and cereal plants, Crop Prot. 22 (2003) $355-360$

[20] R. Bidlan, M. Afsar, H.K. Manonmani, Bioremediation of $\mathrm{HCH}$-contaminated soil elimination of inhibitory effects of the insecticide on radish and green gram seed germination, Chemosphere 56 (2004) 803-811.

[21] Z.S. Siddiqui, S. Ahmed, S.S. Shaukat, Effect of systemic fungicide (Topsin-M) and insecticide (dimecron) on germination, seedling growth and phenolic content of Pennisetum americanum L., Pak. J. Biol. Sci. 2 (1999) 182-184

[22] P.V. Ajithkumar, K.P. Gangadhara, P. Manilal, A.A.M. Kunhi, Soil inoculation with Pseudomonas aeruginosa $3 \mathrm{mT}$ eliminates the inhibitory effect of 3-chloro- and 4-chlorobenzoate on tomato seed germination, Soil Biol. Biochem. 30 (1998) 1053-1059.

[23] K.P. Gangadhara, A.A.M. Kunhi, Protection of tomato seed germination from the inhibitory effect of 2,4,5-trichlorophenoxyaceticacid by inoculation of soil with Burkholderia cepacia AC1100, J. Agric. Food Chem. 48 (2000) 4314-4319.

[24] G.O. Adams, P.T. Fufeyin, S.E. Okoro, I. Ehinomen, Bioremediation, biostimulation and bioaugmention: A review, Int. J. Environ. Bioremediat. Biodegradat. 3(1) (2015) 28-39.

[25] Winardi, E.S. Soetatrto, E. Haryono, Sudrajat, Research roadmap of bioremediation: Review of in situ method on land bioremediation, J. Phys.: Conf. Ser. 1175 (2019) 012130:1-8.

[26] N.V. Pradeep, S. Anupama, K. Navya, H.N. Shalini, M. Idris, U.S. Hampannavar Biological removal of phenol from wastewaters: a mini review, Appl. Water Sci. 5 (2015) 105-112.

[27] L. Zhao, Q. Wu, A. Ma, Biodegradation of phenolic contaminants: Current status and perspectives, Earth Environ. Sci. IOP Conf. Ser. 111 (2018) 012024:1-6.

[28] S.I. Mulla, R.N. Bharagava, D. Belhaj, G.D. Saratale, A. Kumar, et al., Microbial degradation of phenolic compounds, in: A. Kumar, S. Sharma (Eds.), Microbes and enzymes in soil health and bioremediation, Microorganisms for Sustainability, Springer, Nature Singapore Pte Ltd., 2019.

[29] ISTA (International Seed Testing Association), International rules for seed testing, Annexes Seed Science and Technology 13 (1985) 356-513.

[30] ISTA Rules 2009, International Seed Testing Association, Bassersdorf, Switzerland, 2009.

[31] M. Laskowsky, Trypsinogen and trypsin, Methods Enzymol. 11 (1955) 26-36.

[32] P. Bernfeld, Amylases: alpha and beta, Methods Enzymol. 1 (1955) 149-158.

[33] R.J. Lacoste, S.H. Venabe, J.C. Stone, Modified 4-aminoantipyrene colorimetric method for phenol. Application of an acrylic monomer, Anal. Chem. 131 (1959) $1246-1249$.

[34] B. Politycka, K. Seidler-Lożykowska, Phytotoxicity and phenolic compounds content in soil during long-term cultivation of lemon balm (Melissa officinalis L.) and its effect on herb yield and essential oil content, Kerba Polonica 55 (2009) 133-139.

[35] D.P. Komilis, E. Karatzas, C.P. Halvadakis, The effect of olive mill wastewater on seed germination after various treatment techniques, J. Environ. Manage. 74 (2005) 339-348.

[36] J.Q. Yu, Y. Matsui, Extraction and identification of phytotoxic substances accumulated in nutrient solution for the hydroponic culture of tomato, Soil Sci. Plant Nutr. 39 (1993) 691-700.

[37] M.M. Peterson, G.L. Horst, P.J. Shea, S.D. Comfort, R.K.D Peterson, TNT and 4amino-2,6-dinitrotoluene influence on germination and early seedling development of tall fescue, Environ. Pollut. 93 (1996) 57-62.

[38] A.S. Ali, A.A. Elozeiri, Metabolic processes during seed germination, In: J.C. Jimenez-Lopez (Ed.), Advances in Seed Biology, IntechOpen, United Kingdom, 2017, pp.141-146.

[39] K. Rani, S. Kant, S. Goyal, A. Saini, C. Gupta, A novel comparative assessment of extracted amylase activity in germinating and germinated seeds of Cicer arietinum, Ceci neri, and Pisum sativum, Int. J. Pure App. Biosci. 2(2) (2014) 191-193.

[40] P.Y.A. Ahamad, A.A.M. Kunhi, Enhanced degradation of phenol by Pseudomonas sp. CP4 entrapped in agar and calcium alginate beads in batch and continuous processes, Biodegradation 22 (2011) 253-265.

[41] A. Mrozik, S. Miga, Z. Piotrowska-Seget, Enhancement of phenol degradation by soil bioaugmentation with Pseudomonas sp. JS150, J. Appl. Microbiol. 111 (2011) $1357-1370$

[42] P. Radhapriya, A. Ramachandran, R. Anandham, S. Mahalingam, Pseudomonas aeruginosa RRALC3 enhances the biomass, nutrient and carbon contents of Pongamia pinnata seedlings in degraded forest soil, PLoS ONE 10(10) (2015) $1-19$.

[43] R. Hayat, S. Ali, U. Amara, R. Khalid, I. Ahmed, Soil beneficial bacteria and their role in plant growth promotion: a review, Ann. Microbiol. 60 (2010) 579-598. 